\title{
PENGEMBANGAN SISTEM PAKAR MENDETEKSI PENYAKIT PENCERNAAN MENGGUNAKAN METODE NAIVE BAYES BERBASIS WEB
}

\author{
1) Imam Soleh Ma'rifati, 2) Chandra Kesuma \\ 1) Manajemen Informatika, AMIK BSI Purwokerto \\ imam.isr@bsi.ac.id \\ 2) Manajemen Informatika, AMIK BSI Pontianak \\ chandra.cka@bsi.ac.id
}

\begin{abstract}
The digestive system of the human body function to receive and digest food into nutrients absorbed by the body to be distributed to the organs by blood. Gastrointestinal Disease is a disease that attacks the digestive organs that it interferes with the digestive system. Some of the factors that can cause gastrointestinal illnesses among others is unhealthy food, nutritional balance, irregular eating patterns, and infection as well as abnormalities of the digestive organs. Development of expert systems for detecting gastrointestinal diseases intended to assist and facilitate in recognizing and detecting a disturbance in the digestive system. The method used is the Naive Bayes method for analyzing the symptoms of the disease in patients that can be known gastrointestinal illness suffered.Expert systems in this study a web-based application built using HTML 5, PHP and My SQL. Web-based applications allows applications to run on various operating systems for these applications will be run or opened on web browser. Another advantage is that applications can be hosted on a web server and can be accessed by anyone who needs it.
\end{abstract}

\section{Keywords: Expert Systems, Naive Bayes, Digestive Disease, Web Application.}

Abstrak - Sistem pencernaan pada tubuh manusia berfungsi menerima makanan dan mencerna menjadi nutrisi yang diserap oleh tubuh untuk disalurkan ke organ-organ oleh darah. Penyakit pencernaan merupakan penyakit yang menyerang organ pencernaan sehingga mengganggu kerja sistem pencernaan. Beberapa faktor yang dapat menyebabkan penyakit pencernaan antara lain makanan yang kurang baik, keseimbangan nutrisi, pola makan yang tidak teratur, dan infeksi serta kelainan pada organ pencernaan.Pengembangan sistem pakar untuk mendeteksi penyakit pencernaan dimaksud untuk membantu dan mempermudah dalam mengenali dan mendeteksi adanya gangguan pada sistem pencernaan. Metode yang digunakan adalah metode Naive Bayes dalam menganalisa gejala-gejala penyakit pada pasien sehingga dapat diketahui penyakit pencernaan yang diderita.Sistem pakar dalam penelitian ini berupa aplikasi berbasis web yang dibuat menggunakan HTML 5, PHP dan My SQL. Aplikasi berbasis web memungkinkan aplikasi dapat dijalankan di berbagai platform sistem operasi karena aplikasi ini nantinya dijalankan atau dibuka menggunakan browser. Keuntungan lainnya adalah bahwa aplikasi dapat dihosting di sebuah webserver sehingga dapat dibuka oleh siapa saja yang memerlukannya.

\section{Kata Kunci: Sistem Pakar, Naive Bayes, Penyakit Pecernaan, Aplikasi Web.}

\section{A. PENDAHULUAN}

Teknologi informasi dewasa ini telah berkembang pesat dan penggunaannya telah merambah ke berbagai aspek kehidupan manusia. Dewasa ini banyak individu yang menggunakan teknologi informasi untuk membantu pekerjaan atau pun tugas dalam kehidupan sehari-hari.

Sistem pakar merupakan sebuah sistem dalam bentuk aplikasi komputer yang berusaha mengadopsi pengetahuan manusia dalam bentuk program dengan maksud untuk menyelesaikan permasalahan tertentu. Pengetahun mengenai sesuatu dari seorang ahli atau pakar diadopsi ke dalam sebuah sistem pakar (aplikasi komputer) sehingga aplikasi tersebut dapat melakukan diagnosa dan analisis terhadap suatu permasalahan.
Sistem pakar tidak dimaksud untuk menggantikan kemampuan manusia dalam mendiagnosa dan menganlisa permasalahan yang ada. Sistem pakar dapat digunakan sebagai alat bantu oleh orang lain yang tidak memahami suatu permasalahnnya dengan baik sehingga orang tersebut dapat terbantu dalam mengatasi masalah tanpa adanya kehadiran sorang ahli atau pakar.

Penyakit pencernaan adalah penyakit yang menyerang saluran pencernaan. Orang yang terkena penyakit ini akan mengalami gangguan pencernaan seperti diare, maag, dan lain-lain. Pengetahuan pakar (dalam hal ini dokter) mengenai penyakit ini jika dibuat dalam sebuah aplikasi sistem pakar dapat digunakan oleh orang lain dalam mendeteksi kemungkinan 
penyakit gangguan pencernaan yang mungkin diderita.

Hasil diagnosa penyakit pencernaan yang dihasilkan oleh aplikasi sistem pakar tersebut dapat digunakan sebagai bahan pertimbangan atau rujukan awal mengenai penyakit yang dideritanya. Dengan demikian diharapkan orang dapat mengambil tindakan awal secara tepat untuk mencegah atau melakukan tindakan pertama dalam mengatasi penyakitnya tersebut. Di sini peran dokter tetap diperlukan untuk menyimpulkan secara pasti penyakit yang diderita dan pengobatan yang tepat sesuai dengan kondisi orang yang mengalami gangguan penyakit pencernaan.

Pada penelitian ini, penulis tertarik untuk mengembangkan aplikasi sistem pakar tersebut dengan maksud untuk mengetahui bagaimana cara mengembangkan aplikasi sistem pakar untuk menyelesaikan suatu permasalahan khususnya dalam mendiagnosa penyakit saluran pencernaan.

\section{B. TINJAUAN PUSTAKA}

1. Teknologi Informasi dan Komunikasi

Teknologi Informasi dan Komunikasi (information and communication technology) meliputi 2 hal yaitu teknologi komputer dan teknologi komunikasi. Teknologi komputer merupakan seperangkat alat elektronik multiguna yang dapat menerima masukan (input) data, mengolah data, menyimpan program dan hasil pengolahakn data (informasi), menyajikan informasi yang kerjanya dikendalikan oleh sebuah program yang disimpan dalam media penyimpanan dan bekerja secara otomatis. (Suyanto, 2005).

\section{Aplikasi Berbasis Web (Web Apps)}

Dalam ilmu komputer, aplikasi berbasis web (web based application, web apps) adalah aplikasi perangkay lunak client-server di mana klien (atau user interface) berjalan di web browser. Aplikasinya sendiri disimpan di sebuah web server, begitunya data-data disimpan di database server.

Aplikasi berbasis web memudahkan pengembang karena aplikasi ini dapat berjalan di berbagai platform sistem operasi. Tentu saja karena dijalankan melalui web browser. Oleh karena itu aplikasi dapat dijalankan di sistem berbasis Windows, Linux atau Mac. Aplikasi web biasanya menggunakan kombinasi skrip sisi server (sever sides script) seperti PHP atau ASP. Dan skrip sisi klien (cient side scrip) seperti HTML dan Javacsript. Penggunaan skrip sisi klien berkaitan dengan penyajian informasi sementara skrip sisi server berhubungan dengan pengolahan data termasuk pengambilan dan penyimpanan informasi.

\section{Sistem Pakar (Expert System)}

Sistem pakar (expert system) adalah sistem berbasis komputer yang menggunakan pengetahuan, fakta, dan tehnik penalaran dalam memecahkan masalah yang biasanya hanya dapat dipecahkan oleh seorang pakar dalam bidang tersebut. Sistem pakar memberikan nilai tambah pada teknologi untuk membantu dalam menangani era informasi yang semakin canggih. (Kusrini, 2006).

Sistem pakar memungkinkan seseorang yang kurang memahami suatu permasalahan terbantu melalui aplikasi sistem pakar yang dibuat. Permasalahan yang telah diidentifikasi dapat diproses dan diolah sedemikian rupa sehingga dihasilkan suatu kesimpulan mengenai suatu permasalahan.

Tabel 1. Perbedaan pakar manusia dengan sistem pakar

\begin{tabular}{|c|c|}
\hline Pakar Manusia & Sistem Pakar \\
\hline $\begin{array}{l}\text { Terbatas waktu } \\
\text { karena manusia } \\
\text { membutuhkan } \\
\text { istirahat }\end{array}$ & $\begin{array}{lr}\text { Tidak } & \text { terbatas } \\
\text { karena } & \text { dapat } \\
\text { digunakan } & \text { kapanpun } \\
\text { juga } & \end{array}$ \\
\hline $\begin{array}{lr}\text { Tempat } & \text { akses } \\
\text { bersifat lokal } & \text { pada } \\
\text { suatu tempat saja } \\
\text { dimana } & \text { pakar } \\
\text { berada } & \end{array}$ & $\begin{array}{l}\text { Dapat digunakan di } \\
\text { berbagai tempat }\end{array}$ \\
\hline $\begin{array}{l}\text { Pengetahuan } \\
\text { bersifat variable dan } \\
\text { dapat berubah-ubah } \\
\text { tergantung situasi }\end{array}$ & $\begin{array}{l}\text { Pengetahuan } \\
\text { bersifat konsisten }\end{array}$ \\
\hline $\begin{array}{lr}\text { Kecepatan } & \text { untuk } \\
\text { menemukan } & \text { solusi } \\
\text { sifatnya bervariasi }\end{array}$ & $\begin{array}{lr}\text { Kecepatan } & \text { untuk } \\
\text { memberikan } & \text { solusi } \\
\text { konsisten dan lebih } & \text { daripada } \\
\text { cepat } & \text { manusia }\end{array}$ \\
\hline $\begin{array}{lr}\text { Biaya yang } & \text { harus } \\
\text { dibayar } & \text { untuk } \\
\text { konsultasi biasanya } \\
\text { sangat mahal }\end{array}$ & $\begin{array}{l}\text { Biaya } \\
\text { dikeluarkan } \\
\text { murah }\end{array}$ \\
\hline
\end{tabular}

\section{Naive Bayes Classifier}

Naive Bayes Classifier merupakan suatu klasifikasi berpeluang sederhana berdasarkan aplikasi teorema Bayes dengan asumsi antar variabel penjelas saling bebas (independen) yaitu kehadiran atau ketiadaan dari suatu kejadian tertentu dari suatu kelompok tidak berhubungan dengan kehadiran atau ketiadaan dari kejadian lainnya.

Secara umum, teorema Bayes dinyatakan sebagai: 


$$
P(A \mid B)=\frac{P(B \mid A) \cdot P(A)}{P(B)}
$$

Dalam notasi ini $P(A \mid B)$ berarti peluang kejadian $A$ bila $B$ terjadi dan $P(B \mid A)$ peluang kejadian $B$ bila $A$ terjadi.

\section{Penyakit Saluran Pencernaan}

Penyakit adalah suatu keadaan abnormal dari tubuh atau pikiran yang menyebabkan ketidaknyamanan, disfungsi atau kesukaran terhadap orang yang dipengaruhinya (Wikipedia, 2011). Penyakit saluran pencernaan adalah penyakit yang menyerang organ tubuh pada sistem pencernaan manusia. Penyakit saluran pencernaan yaitu :

a) Crohn

Crohn adalah salah satu penyakit radang usus dan merupakan kondisi jangka panjang yang mana peradangan bisa terjadi pada seluruh lapisan dinding sistem pencernaan, mulai dari mulut hingga ke anus.

b) Gastritis

Penyakit gastritis menyebabkan radang yang menyerang pada lambung sehingga penderita akan merasakan rasa perih pada lambung, mual dan panas pada lambung.

c) Maag

Penyakit maag (indigestion) adalah istilah yang menggambarkan nyeri yang berasal dari lambung, usus halus, atau bahkan kerongkongan akibat sejumlah kondisi. Sebutan lain sakit maag adalah dispepsia. Sakit maag bisa disebabkan akibat luka terbuka yang muncul di lapisan dalam lambung (tukak lambung), infeksi bakteri Helicobacter pylori, efek samping penggunaan obat antiinflamasi nonsteroid (OAINS), dan stres.

d) Tukak Lambung

Tukak lambung adalah luka yang muncul pada dinding lambung akibat terkikisnya lapisan dinding lambung. Luka ini juga berpotensi muncul pada dinding bagian pertama usus kecil (duodenum) serta kerongkongan (esofagus).

e) Gastroporesis

Gastroparesis adalah suatu kondisi dimana otot-otot di perut tidak berfungsi secara normal. Biasanya, kontraksi otot yang kuat mendorong makanan melalui saluran pencernaan. Ketika terjadi gastroparesis, otot-otot dinding perut bekerja buruk atau tidak bekerja sama sekali. Hal ini mencegah perut untuk mengosongkan dirinya secara total. Gastroparesis dapat mengganggu pencernaan, menyebabkan mual dan muntah, dan menyebabkan masalah dengan kadar gula darah dan nutrisi.

f) Gastroenteritis

Gastroenteritis adalah infeksi yang terjadi pada usus atau perut yang disebabkan oleh beberapa jenis virus. Kondisi ini juga dikenal dengan istilah flu perut, flu lambung, atau virus perut. Infeksi ini menyebabkan terjadinya mual, muntah, diare, kram perut, dan terkadang demam. Gastroenteritis menyebar melalui kontak jarak dekat dengan orang yang sudah terinfeksi atau karena mengonsumsi makanan dan/atau minuman yang terkontaminasi.

g) Usus buntu

Penyakit usus buntu adalah peradangan atau pembengkakan apendiks atau usus buntu. Sedangkan usus buntu adalah organ berbentuk kantong kecil dan tipis berukuran 5 hingga $10 \mathrm{~cm}$ yang terhubung pada usus besar.

h) Tifus

Tifus (tipes) atau demam tifoid adalah penyakit yang terjadi karena infeksi bakteri Salmonella typhi dan umumnya menyebar melalui makanan dan minuman yang telah terkontaminasi.

i) Gerd

Penyakit asam lambung atau Gastroesophageal Reflux Disease (GERD) adalah masalah yang cukup umum terjadi di masyarakat. Kondisi ini disebabkan oleh naiknya asam lambung menuju esofagus dan menimbulkan nyeri pada ulu hati atau sensasi terbakar di dada.

j) Iritasi Usus Besar

Iritasi usus besar merupakan sebuah gangguan yang paling banyak terjadi pada kolon atau usus besar manusia. Gangguan ini menyebabkan munculnya rasa sakit dan ketidaknyamanan pada perut. Kebanyakan orang tidak menyadari bahwa mereka menderita IBS atau syndrome iritasi usus besar, sebab gejalanya sangat mirip dengan sakit perut biasa.

\section{METODE PENELITIAN}

Dalam pengembangan aplikasi sistem pakar penulis menggunakan metode waterfall, yaitu sebuah pendekatan atau model pengembangan aplikasi dengan membagi proses pengambangan aplikasi menjadi beberapa tahap. Tahap-tahap pengembangan aplikasi meliputi tahap analisa kebutuhan (Requirement Analisis), perancangan sistem (System Design), pengembangan aplikasi (Implementasi), Integrasi dan pengujian 
(Integration \& Testing), penggunaan dan pemeliharaan (Operation \& Maintenance) (Pressman, 2012).

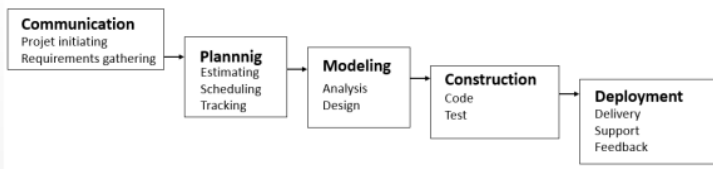

Gambar 1. Waterfall Model

\section{HASIL DAN PEMBAHASAN}

\section{Analisis Menggunakan Naive Bayes}

Aplikasi sistem pakar untuk mendeteksi penyakit pencernaan memerlukan data mengenai penyakit dan gejala-gejala yang dimiliki oleh setiap penyakit. Berikut ini adalah data penyakit dan gejalanya.

Tabel 2. Gejala penyakit pencernaan

\begin{tabular}{|l|l|}
\hline KODE & \multicolumn{1}{|c|}{ GEJALA } \\
\hline G1 & Mual \\
G2 & Kembung \\
G3 & Hilang (berkurang) nafsu makan \\
G4 & Muntah \\
G5 & Diare \\
G6 & Tinja bercampur darah \\
G7 & Nyeri perut \\
G8 & Demam \\
G9 & Dada terasa terbakar \\
G10 & Kram perut \\
G11 & Sesekali muntah darah \\
G12 & Sering muntah darah \\
G13 & Perih dari leher sampai perut \\
G14 & Nyeri di leher, pusar dan punggung \\
G15 & Nyeri ulu hati \\
G16 & Berat badan turun drastis \\
G17 & Lidah berwarna putih \\
G18 & Sakit saat buang air \\
\hline
\end{tabular}

Tabel 3. Penyakit dan gejalanya

\begin{tabular}{|l|l|}
\hline \multicolumn{1}{|c|}{ PENYAKIT } & \multicolumn{1}{c|}{ GEJALA } \\
\hline Crohn & $\mathrm{G} 1, \mathrm{G} 3, \mathrm{G} 6, \mathrm{G} 7$ \\
Gastritis Akut & $\mathrm{G} 1, \mathrm{G} 2, \mathrm{G} 3, \mathrm{G} 4$ \\
Gastritis Kronis & $\mathrm{G} 1, \mathrm{G} 3, \mathrm{G} 6, \mathrm{G} 12$ \\
Maag & $\mathrm{G} 1, \mathrm{G} 3, \mathrm{G} 7, \mathrm{G} 13$ \\
Tukak Lambung & $\mathrm{G} 1, \mathrm{G} 3, \mathrm{G} 7, \mathrm{G} 14$ \\
Gastriporesis & $\mathrm{G} 1, \mathrm{G} 3, \mathrm{G} 4, \mathrm{G} 15$ \\
Gastroenteristis & $\mathrm{G} 1, \mathrm{G} 3, \mathrm{G} 4, \mathrm{G} 16$ \\
Usus Buntu & $\mathrm{G} 1, \mathrm{G} 3, \mathrm{G} 4, \mathrm{G} 8, \mathrm{G} 18$ \\
Tifus & $\mathrm{G} 1, \mathrm{G} 4, \mathrm{G} 8, \mathrm{G} 17$ \\
Gerd & $\mathrm{G} 1, \mathrm{G} 4, \mathrm{G} 9$ \\
Iritasi Usu Besar & $\mathrm{G} 1, \mathrm{G} 5, \mathrm{G} 10$ \\
\hline
\end{tabular}

Proses analisa klasifikasi Naive Bayes, misalkan seseorang mengalami gejala : Mual (G1), Kembung (G2), Hilang (berkurang) nafsu makan (G3) dan Muntah (G4), maka perhitungannya adalah sebagai berikut :

a) Menentukan Naive Bayes Classifier (nc) Penyakit 1 (Crohn) :
$\mathrm{N}=1$

$P=1 / 11=0.0909090909091$

$M=18$

$\mathrm{G} 1 . \mathrm{nc}=1$

$\mathrm{G} 2 \cdot \mathrm{nc}=0$

$\mathrm{G} 3 \cdot \mathrm{nc}=1$

$\mathrm{G} 4 . \mathrm{nc}=0$

b) Menghitung probabilitas penyakit 1 (Crohn):

$1+18 \times 0.0909090909091$

$\mathrm{P}(\mathrm{G} 1 \mid$ Crohn $)=$

- 0.138755980861

$$
1+18
$$

$0+18 \times 0.0909090909091$

$\mathrm{P}(\mathrm{G} 2 \mid$ Crohn $)=$

P $\quad 0.0861244019139$

$$
1+18
$$

$1+18 \times 0.0909090909091$

$\mathrm{P}(\mathrm{G} 3 \mid$ Crohn $)=$

P(G3|Crohn $=0.138755980861$

$$
1+18
$$

$0+18 \times 0.0909090909091$

$\mathrm{P}(\mathrm{G} 2 \mid$ Crohn $)=$

--- $\quad 0.0861244019139$

$$
1+18
$$

c) Menghitung $P(A \mid B) \times P(B)$ pada penyakit 1 (Crohn)

$=\quad(P) X P(G 1 \mid$ Crohn $) X$
$P(G 2 \mid$ Crohn $) X$
$P(G 3 \mid$ Crohn $) X P(G 4 \mid$ Crohn $)$
$=0.0909090909091 \times 0.138755980861$
$X 0.0861244019139 \times 0.138755980861$
$X 0.0861244019139$
$=\quad 1.29826448379 E-5$

Hitung dengan cara yang sama untuk semua penyakit, hasilnya adalah :

Tabel 4. Hasil Perhitungan Peluang Penyakit

\begin{tabular}{|l|r|}
\hline \multicolumn{1}{|c|}{ Penyakit } & \multicolumn{1}{c|}{ Hasil } \\
\hline Gastritis akut & $3.36987787306 \mathrm{E}-5$ \\
Gastroporesis & $2.091648335 \mathrm{E}-5$ \\
Gastroenteritis & $2.091648335 \mathrm{E}-5$ \\
Usus buntu & $2.091648335 \mathrm{E}-5$ \\
Crohn & $1.29826448379 \mathrm{E}-5$ \\
Gastritis kronis & $1.29826448379 \mathrm{E}-5$ \\
Maag & $1.29826448379 \mathrm{E}-5$ \\
Tukak lambung & $1.29826448379 \mathrm{E}-5$ \\
Tifus & $1.29826448379 \mathrm{E}-5$ \\
Gerd & $1.29826448379 \mathrm{E}-5$ \\
Iritasi usus besar & $8.05819334768 \mathrm{E}-6$ \\
& \\
\hline
\end{tabular}

Berdasarkan hasil perhitungan pada tabel 4 dapat disimpulkan bahwa orang tersebut terkena penyakit Gastritis akut dengan nilai tertinggi yaitu : 3.36987787306E-5. 


\section{Desain Aplikasi}

a) Halaman diagnosa gejala penyakit. Halaman ini digunakan untuk mengisi gejala penyakit yang dialami pasien.

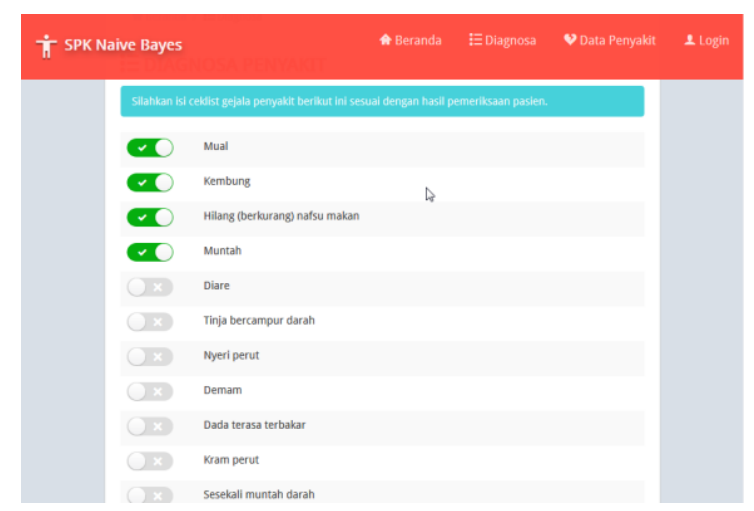

Gambar 2. Halaman Diagnosa

b) Halaman hasil diagnosa. Halaman ini menampilkan hasil analisis menggunakan metode Naive Bayes.

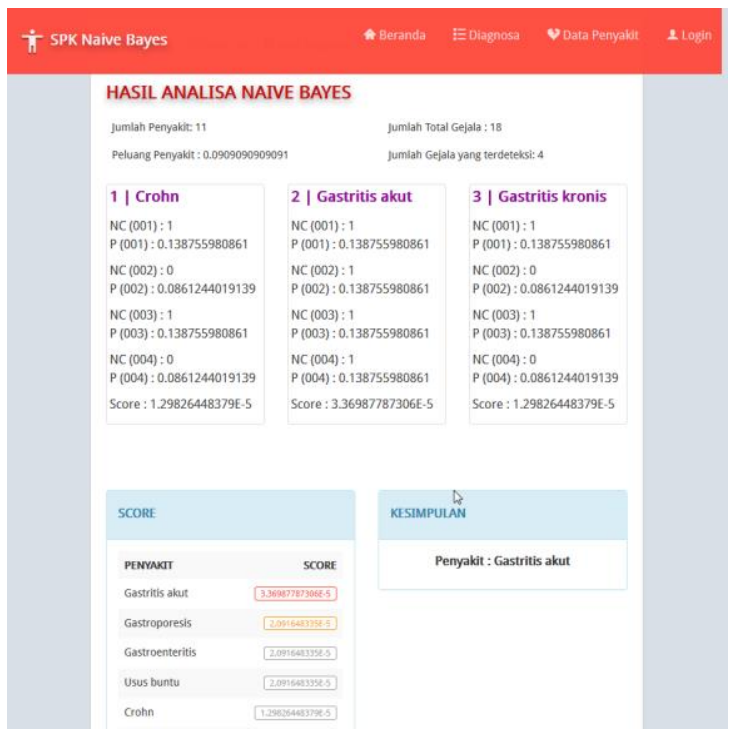

Gambar 3. Halaman hasil analisis

c) Halaman daftar penyakit. Halaman ini menampilkan daftar penyakit yang ada dalam basis data yaitu penyakit yang dapat dideteksi oleh aplikasi.

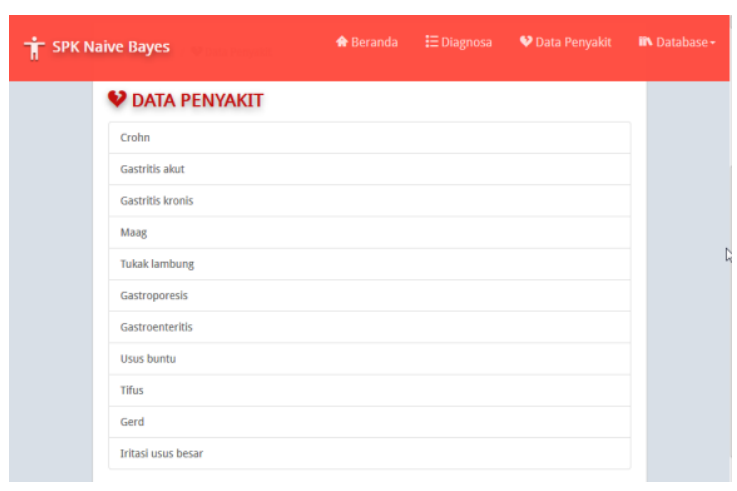

Gambar 4. Halaman data penyakit.

d) Halaman Informasi Penyakit. Halaman ini menyajikan informasi penyakit pencernaan dan solusi pencegahannya.

\section{\ INFORMASI PENYAKIT}

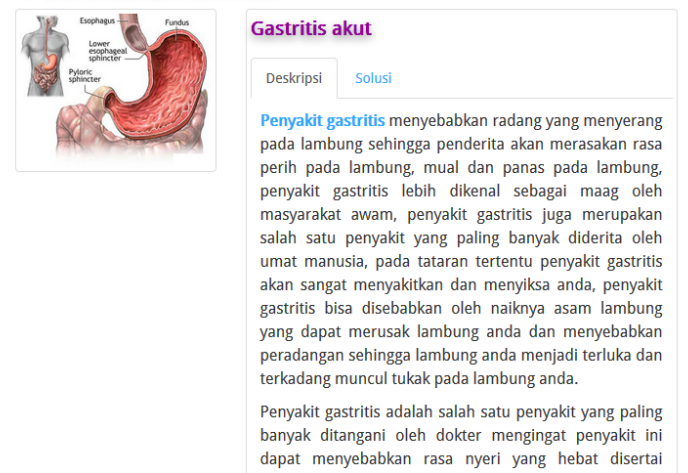

Gambar 5. Halaman informasi penyakit.

e) Halaman Login Administrator. Halaman ini menampilkan form login untuk administrator.

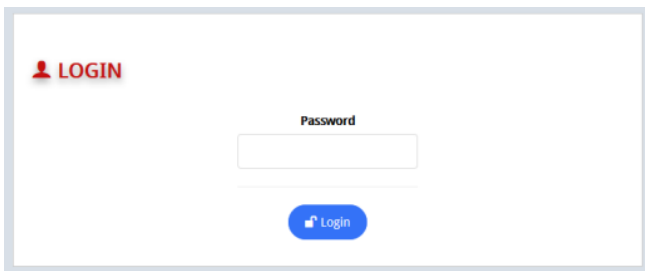

Gambar 6. Halaman login

f) Menu administrator. Halaman ini menampilkan menu yang berisi fasilitas administrasi data. 


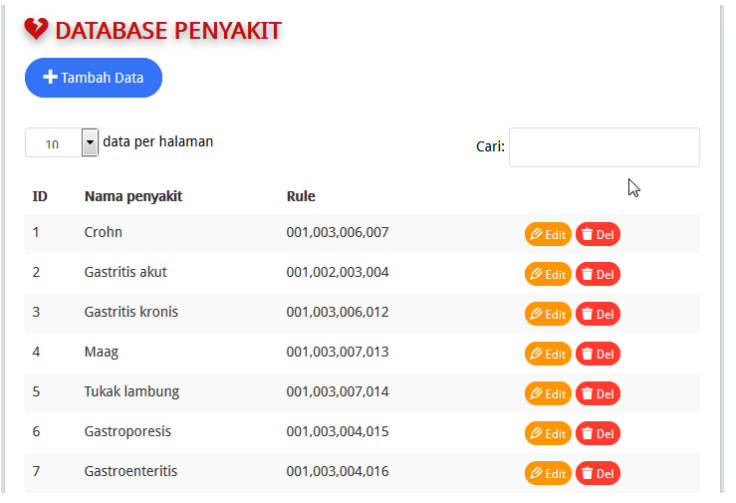

Gambar 7. Administrasi data penyakit

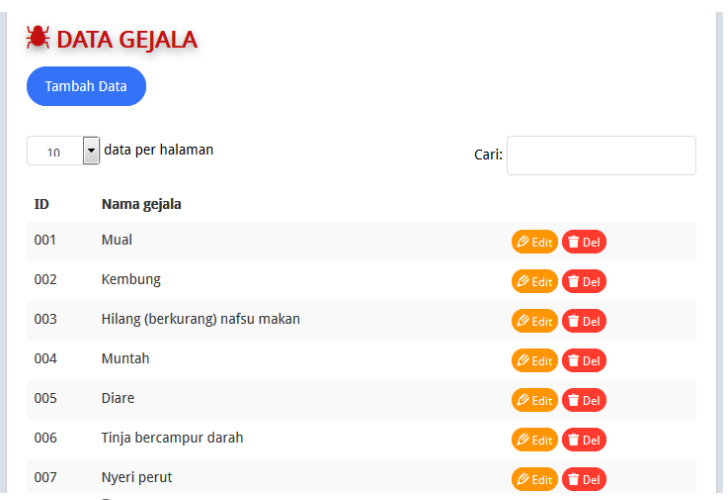

Gambar 8. Administrasi data gejala

\section{Pemrograman}

Aplikasi sistem pakar berbasis web menggunakan bahasa pemrograman HTML 5, PHP dan basis data My SQL. Sedangkan server web yang digunakan dalam tahap pengembangan adalah XAMPP.

a) Basis Data

Basis data digunakan untuk menyimpan informasi yang diperlukan dalam proses analisis data gejala yang diinput oleh pengguna. Di dalam sebuah basis data digunakan tabel-tabel yang berfungsi untuk menyimpan data-data tertentu. Dalam aplikasi sistem pakar ini, tabel yang digunakan adalah:

1) Tabel Penyakit (tbpenyakit), dengan struktur :

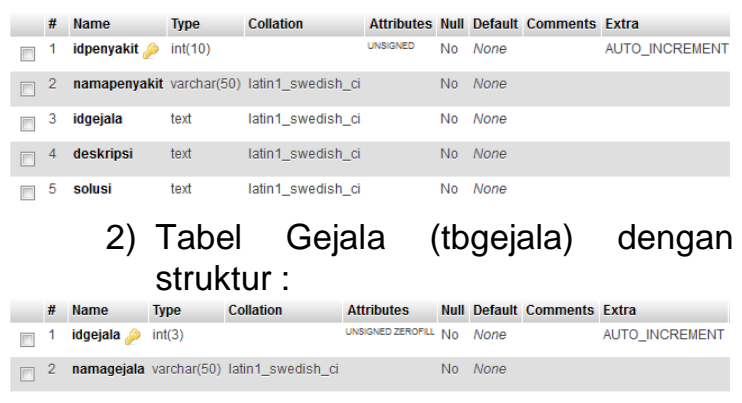

b) Program PHP

Program menggunakan bahasa pemrograman web yaitu php. Berikut

adalah bagian program yang berfungsi melakukan perhitungan menggunakan algoritma Naive Bayes berdasarkan gejala yang diinput oleh pengguna :

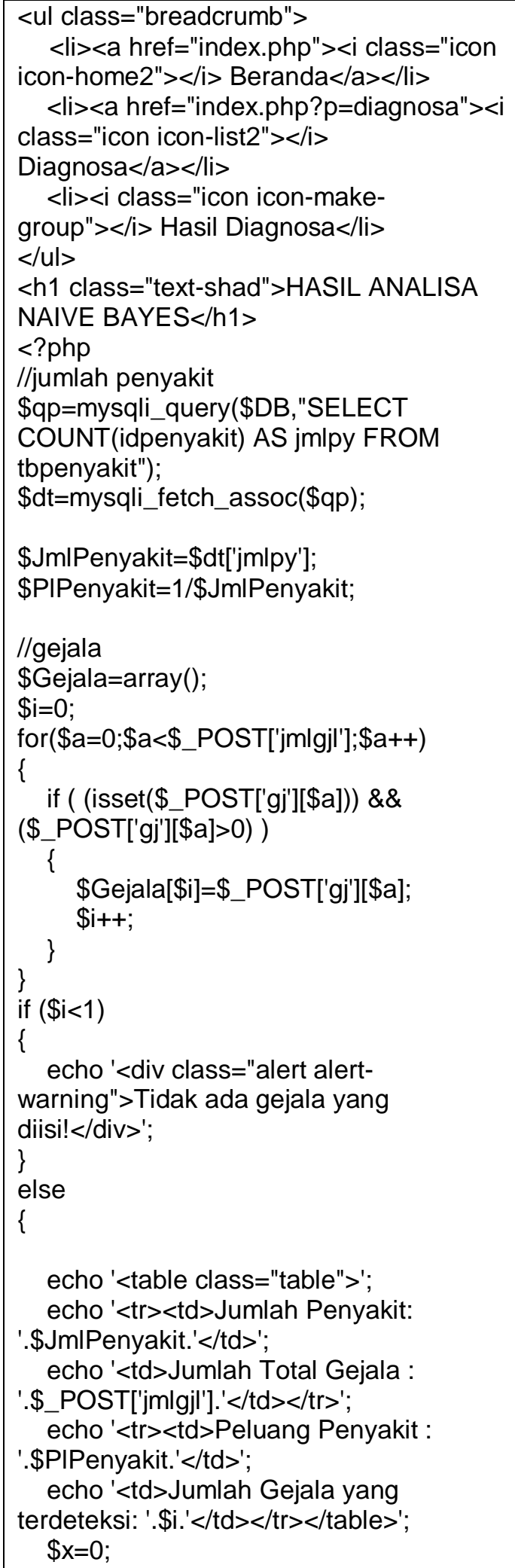



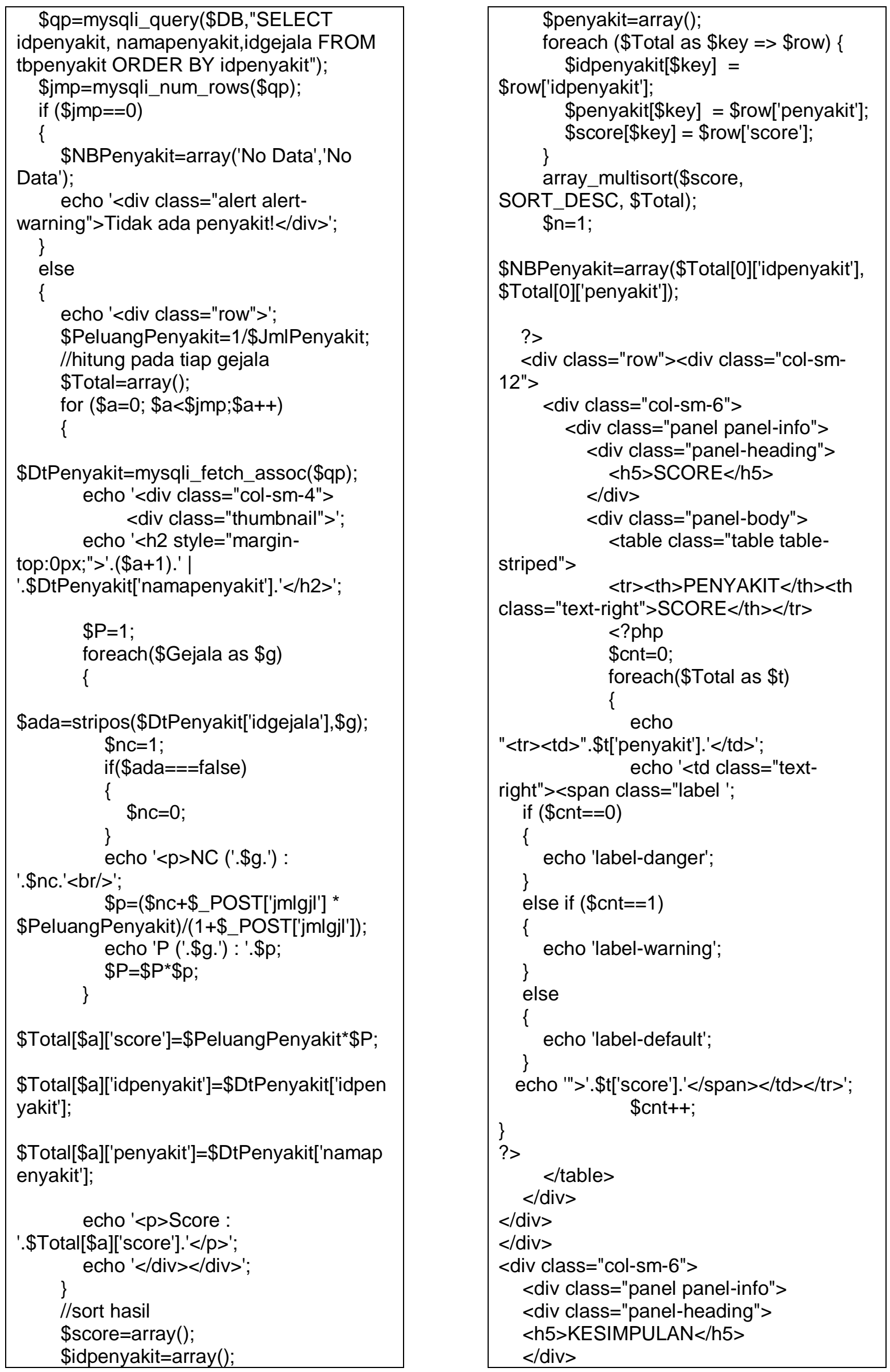


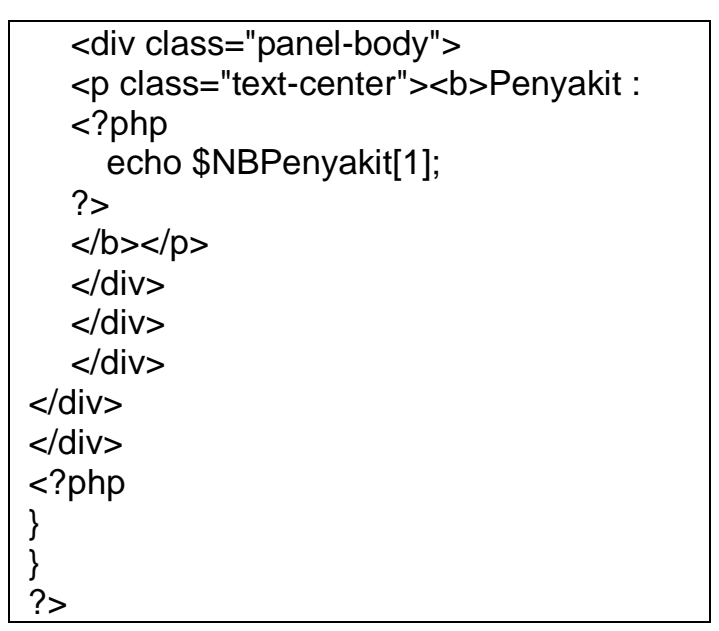

\section{E. KESIMPULAN}

Berdasarkan pembahasan pada bab sebelumnya dapat disimpulkan sebagai berikut: 1. Metode Naive Bayes dapat digunakan sebagai metoda dalam proses analisis untuk mendeteksi penyakit pencernaan dalam bentuk aplikasi sistem pakar.

2. Aplikasi sistem pakar dapat digunakan untuk membantu orang awam (tidak memiliki keahlian) untuk mendeteksi penyakit yang mungkin diderita oleh seseorang.

3. Terkait dengan masalah penanganan penyakit pencernaan, meskipun sistem pakar dapat memberikan kesimpulan penyakit yang terdeteksi, tetap diperlukan tenaga medis yang berkompeten untuk menangani penyakit tersebut.

4. Informasi pencegahan penyakit yang disajikan oleh aplikasi sistem pakar dapat digunakan sebagai rujukan pencegahan penyakit sehingga langkah awal dapat diterapkan untuk menghindari semakin parahnya penyakit yang diderita.

\section{DAFTAR PUSTAKA}

[1] Anggraeni, Nur., Diana Rahmawati, Firli Irhamni. 2012. Sistem Penentuan Status Gizi Pasien Rawat Inap Menggunakan Metode Naive Bayes Classifier, Jurnal
Sarjana Teknik Informatika, vol. 1, no. 1, pp. 85 - 92, November 2012.

[2] Irwansyah, Edy, Jurike V. 2014. Pengantar Teknologi Informasi. Yogyakarta: Deepublish (ISBN : 978-602-280-309-0)

[3] Kusrini. 2006. Sistem Pakar Teori dan Aplikasi, Yogyakarta : Andi

[4] Masriah, Bambang Eka Purnama, Ery Widiyanto, Sistem Pakar Pendeteksi Kerusakan Pada Mobil Kijang Grand, Jurnal Speed 6 Volume 6 Nomor 1 Februari 2009, ISSN 1979 - 9330

[5] Mulyanto, Agus. 2009. Sistem Informasi Konsep dan Aplikasi. Yogyakarta: Andi

[6] Penerbit Andi. 2009. Pengembangan Sistem Pakar menggunakan Visual Basic. Yogyakarta: CV Andi Offset

[7] Pressman, Roger S. 2012. Rekayasa Perangkat Lunak - Buku Satu, Pendekatan Praktisi (Edisi 7). Yogyakarta: Andi.

[8] Sutanta, Edhy. 2011. Basis Data Dalam Tinjauan Konseptual. Yogyakarta: Andi

[9] Suyanto, M. 2005. Pengantar Teknologi Informasi Untuk Bisnis. Yogyakarta: Andi (ISBN: 979-731-812-5)

[10] Turnip, Mardi. 2015. Sistem Pakar Diagnosa Penyakit THT Menggunakan Metode Backward Chaining. Riau Journal Of Computer Science Vol.1/No.1/2015

[11] Wikipedia. $2011 . \quad$ Penyakit, http://id.wikipedia.org/wiki/Penyakit diakses tanggal 12 Juni 2011 